\title{
Volume 37, 2000 \\ Year-end Author Index
}

Anderson, A.J., Bassett, W.A., Chou, I-M., Jayanetti, S., and Mayanovic, R.A. X-ray spectroscopic investigations of the hydration structure of aqueous $\mathrm{La}^{3+}$ at elevated pressures and temperatures, 104

Ayuso, R.A. See Stewart, D.B., 41

Baker, D. See Kontak, D.J., 115

Baltzer, K.B., Spooner, I., and Raeside, R. The Pacific Decadal Oscillation and its effects on the climate on northwestern British Columbia and southeastern Alaska, 104

Barker, M.L., Spooner, I., and Ethier, M. The development of a Geographic Information System environmental hazard prediction model for Cheticamp River, Cape Breton Island, Nova Scotia, 105

Barr, S.M., and White, C.E. New geological maps of the Pocologan - Saint John area, southern New Brunswick: implications for terrane interpretation, 105

Barr, S.M. See Ethier, M., 44; Hagan, D.M., 198; McLaughlin, K.J., 119; Ténière, P.J., 127; White, C.E., 130; White, C.E., 130

Bassett, W.A. See Anderson, A.J., 104

Beane, R. See Van Vleck, H., 129

Beane, R.J. See Van Vleck, H.E., 3

Berry IV, H.N., and Osberg, P.H. A suggestion from midcoast Maine correlation enthusiasts, 106

Boric, R., and Zentilli, M. Geology, mineral zoning, and lithogeochemistry of hydrothermal alteration at the El Soldado Manto Type Copper Deposit, Chile, 106

Bothner, W.A. See Marvinney S.G., 118

Burden, E. See Young, J., 201

Burridge, C. A new method of simultaneous analysis of isotopic composition and abundance, 198

Byron, J., Cameron, B., Ferry, M., Franko, J., Gould, R., Hagan, D., Hayward, B., Jodrey, M., Johnston, K., Paul. H., Spooner, I., Stokes, M., White, J., and White, W. Petrology, depositional environment, and economic potential of sandstone beds within the Horton Bluff Formation in the Windsor region, central Nova Scotia, 107

Calon, T. See Young, J., 201

Cameron, B. See Byron, J., 107

Chakungal, J., Reynolds, P.H., Jamieson, R.A., and Corrigan, D. ${ }^{40} \mathrm{Ar} /{ }^{39} \mathrm{Ar}$ traverse across the Reindeer Zone, Trans-Hudson Orogen, Reindeer Lake, Saskatchewan, 107

Chatterjee, A.K. See MacDonald, H., 116

Chou, I-M. See Anderson, A.J., 104

Corrigan, D. See Chakungal, J., 107

Courtney, R. See Hoehen, J., 113

Cousineau, P. See Marvinney S.G., 118

Csank, A.Z. A Late Cretaceous polar forest from NW Ellesmere Island: implications for climate, past and future, 198

Culshaw, N. See Kontak, D.J., 115 de Jonge, A. The geology of the Fogo seamounts, 108

De Wolfe, M., Kontak, D.J., and Dostal, J. Petrological evidence for extensive liquid immiscibility in the Jurassic North Mountain Basalt, Nova Scotia, 108

Donovan, S.K. See Pickerill, R.K., 122

Dostal, J. See De Wolfe, M., 108; MacDonald, H., 116

Durling, P., and Martel, T. Seismic stratigraphy and structural setting of the McCully gas field, 109

Durling, P. See Martel, T., 118

Ethier, M., Barr, S.M., Raeside, R.P., and Webster, T. Reinterpretation of the geology of the Cape Breton Highlands using combined remote sensing and geological databases, 44

Ethier, M. See Barker, M.L., 105; White, C.E., 130

Falcon-Lang, H.J. Fire ecology of a Late Carboniferous floodplain, Joggins, Nova Scotia, 109

Feltham, G. Stratigraphy and structure of mélange in the Humber Arm allochthon at Bear Cove, western Newfoundland, 198

Ferry, M. See Byron, J., 107

Forbes, W.H. See Miller, R.F., 191

Fowler, M.G. See Shimeld, J.W., 126

Franko, J. See Byron, J., 107

Fyffe, L. See van Staal, C.R., 128

Fyffe, L.R. Stratigraphy and geochemistry of Ordovician volcanic rocks of the Eel River area, west-central New Brunswick, 91

Fyffe, L.R., and Grant, R.H. Pre-Mesozoic stratigraphy of Grand Manan Island and possible correlation with the Ellsworth terrane in coastal Maine, 110

Fyffe, L.R., McNicoll, V., and van Staal, C. Provenance of detrital zircons from the Silurian Oak Bay conglomerate of southwestern New Brunswick, 111

Gauley, B.L., and Piper, D.J.W. Lithostratigraphy and sediment failure on the central Scotian Slope, 111

Gibling, M.R., Nguyen, M., Martel, A.T., and Naylor, R.D. Diagenetic and burial history of Upper Carboniferous sandstone, Sydney Basin, 112

Gingras, M.K., and Pemberton, S.G. Trace fossils are useful - an example from Willapa Bay, Washington, 112

Gingras, M.K. See Price, G.B., 122

Goodwin, T.A. See Page, K.D., 121

Gould, R. See Byron, J., 107

Grant, R.H. See Fyffe, L.R., 110

Grieve, R.A.F. See Whitehead, J., 131

Hagan, D.M. and Barr, S.M. Volcanic rocks in the White Rock Formation in the Torbrook area, Nova Scotia: petrology and tectonic setting, 198

Hagan, D. See Byron, J., 107

Hawkes, A. Evidence of precursor events for mega-thrust earthquakes on the West Coast of North America, 113

Hayward, B. See Byron, J., 107

Hoehne, J., Louden, K., and Courtney, R. Seismic 
velocities and reflection sequences of Wisconsinan glaciation in Emerald Basin (Scotian Shelf), 113

Horne, R.J. See Kontak, D.J., 115; See White, C.E., 130

Howells, K., and Ruffman, A. Modifications of gravity interpretations for the Shubenacadie-Stewiacke Carboniferous Basin, Nova Scotia, 114

Ingram, S., and Pe-Piper, G. The New Cornwall syenogranite, Nova Scotia: petrology and geochemistry, 114

Ingram, S. See Pe-Piper, G., 133

Ings, S. and Owen, J.V. Decompressional reaction textures in the southeast Long Range inlier, Newfoundland: products of thermal metamorphism adjacent to the Taylor Brook gabbro complex? 199

Isenor, F.M., Spooner, I.S., and McClenaghan, M.B. Applied Quaternary geology and till geochemistry of the Loch Lomond region, Cape Breton Island, Nova Scotia, 114

Jamieson, R.A. See Chakungal, J., 107

Jauer, C.D. See MacRae, A., 117

Jayanetti, S. See Anderson, A.J., 104

Jodrey, M. See Byron, J., 107

Johnson, S.C. Contrasting geology in the Pocologan River and Long Reach areas: implications for the New River belt and correlations in southern New Brunswick and Maine, 61

Johnson, S.C. The New River terrane revisited: insights into the relationship with the St. Croix and Ellsworth terranes in New Brunswick and Maine, 115

Johnston, K. See Byron, J., 107

Keighley, D. See Sinnott, K., 126

Ketchum, J.W.F. See White, C.E., 130; White, C.E., 130

Kiefer, T. See Park, M-H., 153

King, M.S. See White, C.E., 130

Kontak, D.J., Horne, R.J., Baker, D., and Culshaw, N. An integrated structural, fluid inclusion, and stable isotope study of auriferous veins, The Ovens, southern Nova Scotia, 115

Kontak, D.J. See De Wolfe, M., 108

Lentz, D.R. See Thorne, K.G., 175

Louden, K. See Hoehen, J., 113

Lux, D.R. See McLeod, M.J., 17; Stewart, D.B., 41

MacCarthy, K.A., Ryder, G., and Spray, J.G. How are rocks stuck together in waterless environments? 199

MacDonald, H., Dostal, J., and Chatterjee, A.K. Proterozoic calc-silicate rocks of the Oaxaca complex (southern Mexico): an example of sabkha evaporites, 116

MacDonald, I.M.L., and Spooner, I.S. Late-glacial and Holocene stratigraphy of Piper Lake, Pictou County, Nova Scotia: evidence for Younger-Dryas perennial ice cover and sustained landscape instability during the Early Holocene, 116

MacDonald, L.A. See White, C.E., 130

MacKay, P.A. See Waldron, J.W.F., 129

MacMillan, W.C. See Shimeld, J.W., 125
MacNeil, D. Ultramafic rocks in a Neoproterozoic arc, Antigonish Highlands, Nova Scotia, 200

MacRae, A., and Jauer, C.D. Sequence stratigraphy and palynology, Upper Missisauga Formation, Glenelg area, offshore Nova Scotia, 117

MacRae, R.A., Shimeld, J.W., and Wielens, H.J.B.W. Sequence stratigraphy and hydrocarbon potential of regional Upper Cretaceous limestone units, offshore Nova Scotia, 117

MacRae, R.A. See Shimeld, J.W., 126

Marquis, R., See Marvinney S.G., 118

Martel, A.T. See Gibling, M.R., 112

Martel, T., and Durling, P. The petroleum geology of the McCully \#1 gas discovery, 118

Martel, T. See Durling, P., 109

Marvinney, S.G., Moench, R.H., Marquis, R., Cousineau, P., and Bothner, W.A. Resolved Silurian-Devonian stratigraphic correlation across the Québec-Maine-New Hampshire borders and its bearing on Silurian extension, 118

Masaitis, V.L. See Whitehead, J., 131

Mayanovic, R.A. See Anderson, A.J., 104

McClenaghan, M.B. See Isenor, F.M., 114

McCutcheon, S. See van Staal, C.R., 128

McLaughlin, K.J., and Barr, S.M. The Baring Granite and St. Stephen Gabbro of New Brunswick and Maine: petrology, geochemistry, and tectonic setting, 119

McLeod, M.J., Pickerill, R.K., and Lux, D.R. Mafic intrusions on Campobello Island: implications for New Brunswick - Maine correlations, 17

McNicoll, V. See Fyffe, L.R., 111; van Staal, C.R., 128

Miller, R.F., and Forbes, W.H. An Upper Carboniferous trigonotarbid, Aphantomartus pustulatus (Scudder, 1884), from the Maritimes Basin (Euramerican Coal Province), New Brunswick, Canada, 191

Mireku, L.K., and Stanley, C.R. Geology, geochemistry, and hydrothermal alteration of the Lower AB Zone, Halfmile Lake North volcanic hosted massive sulphide deposit, Bathurst, New Brunswick, 119

Moench, R.H. See Marvinney S.G., 118

Moir, P.N. See Shimeld, J.W., 126

Mott, R.J. See Stea, R.R., 127

Muir, C.M. See White, C.E., 130

Murphy, A.J., and Spray, J.G. Type and nature of sulphides in the Whistle-Parkin Offset Dyke, Sudbury impact structure, Ontario, Canada, 120

Murphy, J.B. Geochemistry, provenance, and tectonic significance of sedimentary rocks of the Middle to Late Devonian McArras Brook and Viséan Martin Road formations, Merigomish Subbasin, northern Antigonish Highlands, Nova Scotia, 161

Naylor, R.D. See Gibling, M.R., 112

Neuman, R.B. See Poole, W.H., 122

Nguyen, M. See Gibling, M.R., 112

Nielsen, E. See Ruffman, A., 124

O'Beirne-Ryan, A.M., Ryan, R.J., and Zentilli, M. When has a rounded cobble not traveled far? Recycling of corestones from weathered granitoids: examples from the 
South Mountain Batholith in Nova Scotia, Canada, 120

O'Connell, J.F., and Stanley, C.R. Structural orientations, architecture, and timing of auriferous quartz veins associated with mesothermal saddle reef stockwork gold mineralization, The Ovens, Lunenburg County, Nova Scotia, 121

Osberg, P.H. See Berry IV, H.N., 106

Owen, J.V. See Ings, S., 199

Page, K.D., and Goodwin, T.A. Cycling of mercury in southwest Nova Scotia: Kejimkujik National Park, 121

Park, M-H., Kiefer, T., and Zahn, R. Surface- and deepwater hydrography and meltwater events in the midlatitude North Atlantic Ocean over the past 160,000 years, 153

Paul, H. Petrology and lithogeochemistry of volcanic rocks hosting seafloor hot springs systems in the Manus basin, southwest Pacific Ocean, 200

Paul. H. See Byron, J., 107

Pemberton, S.G. See Gingras, M.K., 112

Pe-Piper, G. and Ingram, S. The New Cornwall syenogranite, Nova Scotia: petrology and geochemistry, 133

Pe-Piper, G. See Ingram, S., 114

Pickerill, R.K., Donovan, S.K., and Portell, R.W. Trace fossils are useful - an example from the Caribbean, 122

Pickerill, R.K. See McLeod, M.J., 17

Piper, D.J.W. See Gauley, B.L., 111

Poole, W.H., and Neuman, R.B. Lower Ordovician (Arenig/Llanvirn) fossiliferous volcaniclastic rocks, western New Brunswick and adjacent Maine, 122

Portell, R.W. See Pickerill, R.K., 122

Power, C. Metamict zircons from the Georgeville pluton, 200

Price, G.B., and Gingras, M.K. Core analysis of the Hiram Brook Member of the Upper Albert Formation, interpretation of the depositional environment, and determination of reservoir prospectivity, 122

Raeside, R. See Baltzer, K.B., 104; Ethier, M., 44

Reusch, D.N. Geology of the Newbury Neck 1:24,000 quadrangle, coastal Maine, 123

Reynolds, P.H. See Chakungal, J., 107; White, C.E., 130

Riggs, K. Heavy metal particulates in the soil surrounding the Tilt Cove smelter, Newfoundland, 201

Rogers, N. See van Staal, C.R., 128

Roulston, B. The role of chance in exploration: the McCully \#1 gas discovery - an example from southern New Brunswick, 124

Ruffman, A., Nielsen, E., and St. George, S. The development of softwood tree-ring chronologies in Nova Scotia: a tool for palaeoclimate reconstruction, archaeological, and heritage building research, 124

Ruffman, A. As we look forward to the year 2001 hurricane season: remembering the Saxby Gale of 1869, 124

Ruffman, A. See Howells, K., 114

Ryan, R.J. See O'Beirne-Ryan, A.M., 120

Ryder, G. See MacCarthy, K.A., 199

Schrumm, L. The use of foraminifera and thecamoebians as freshwater/marine transition zones in mangrove environments of southern Florida, 125

Shimeld, J.W., MacMillan, W.C., and Williams, G.L. The future of the world's oil supply: are we over a barrel?, 125

Shimeld, J.W., Moir, P.N., Fowler, M.G., Stasiuk, L.D., MacRae, R.A., and Williamson, M.A. Heavy oil accumulations in the Jeanne d'Arc Basin: a case study in the Hebron, Ben Nevis, and West Ben Nevis oil fields, 126

Shimeld, J.W. See MacRae, R.A., 117

Sinnott, K., and Keighley, D. Distribution and petrology of sandstone identified in core from the Dawson Settlement Member, Albert Formation (Carboniferous), Moncton Basin, New Brunswick, 126

Skilliter, D.M. Trace fossils of eastern Canada: a traveling exhibit prepared by the Nova Scotia Museum of Natural History, 127

Spooner, I.S. See Baltzer, K.B., 104; Barker, M.L., 105; Byron, J., 107; Isenor, F.M., 114; MacDonald, I.M.L., 116

Spray, J. See Tuchscherer, M., 128

Spray, J.G. See MacCarthy, K.A., 199; Murphy, A.J., 120; Whitehead, J., 131

St. George, S. See Ruffman, A., 124

Stanley, C.R. See Mireku, L.K., 119; O’Connell, J.F., 121

Stasiuk, L.D. See Shimeld, J.W., 126

Stea, R.R., and Mott, R.J. Evidence of the Younger Dryas re-activation of a Gulf of St. Lawrence glacier from the "great ditch" of Nova Scotia, 127

Stewart, D.B., Tucker, R.D., Ayuso, R.A., and Lux, D.R. Minimum age of the Neoproterozoic Seven Hundred Acre Island Formation and the tectonic setting of the Islesboro Formation, Islesboro block, Maine, 41

Stokes, M. See Byron, J., 107

Ténière, P.J., Barr, S.M., and White, C.E. Stratigraphy and structure of the Horton Group in the Lochaber-Mulgrave area, Nova Scotia, 127

Thorne, K.G., and Lentz, D.R. Geochemistry and petrogenesis of the East Branch Brook metagabbroic dykes in the Sawyer Brook fault zone, Clarence Stream gold prospect, southwestern New Brunswick, 175

Tuchscherer, M. and Spray, J. The Foy Offset Dike, Sudbury impact structure, Ontario, Canada, 128

Tucker, R.D. See Stewart, D.B., 41

van Staal, C. See Fyffe, L.R., 111

van Staal, C.R., Rogers, N., Wilson, R., Fyffe, L., McCutcheon, S., and McNicoll, V. Tectonic history of the Popelogan arc - Tetagouche-Exploits back-arc system in New Brunswick and adjacent Maine, 128

Van Vleck, H., and Beane, R. Petrography and geochemistry of mafic blocks in the Hurricane Mountain mélange in west-central Maine, 129

Van Vleck, H.E., and Beane, R.J. Geochemical comparison of mafic, felsic, and ultramafic rocks in the Hurricane Mountain mélange to the Boil Mountain ophiolite complex, west-central Maine, 3

Waldron, J.W.F., and MacKay, P.A. Repetitions in the Kennetcook basin - structural or stratigraphic? 
Implications of field and seismic investigations in the Cheverie-Walton area, Nova Scotia, 129

Webster, T. See Ethier, M., 44

White, C.E., Barr, S.M., Ketchum, J.W.F., and Ethier, M. Geology of the Cape Porcupine Complex, Guysborough County, Nova Scotia, 130

White, C.E., Horne, R.J., King, M.S., MacDonald, L.A., Barr, S.M., Muir, C.M., Reynolds, P.H., and Ketchum, J.W.F. New insights on the geology of the southwestern Meguma terrane, Nova Scotia, 130

White, C.E. See Barr, S.M., 105; Ténière, P.J., 127

White, J. See Byron, J., 107

White, W. See Byron, J., 107

Whitehead, J., Grieve, R.A.F., Spray, J.G., and Masaitis, V.L. Shock metamorphic minerals in the Popigai impact structure, Siberia, 131

Wielens, H.J.B.W. See MacRae, R.A., 117
Williams, G.L. See Shimeld, J.W., 125

Williamson, M.A. See Shimeld, J.W., 126

Wilson, P. Upper-crustal fault processes in southern New Brunswick, 131

Wilson, R. See van Staal, C.R., 128

Wilson, R.A. Geochemistry and regional correlation of Middle Ordovician arc-related volcanic rocks from the Popelogan Inlier (Dunnage Zone), northern New Brunswick, 132

Young, J., Calon, T., and Burden, E. Stratigraphy and structure of the Humber Arm allocthon, southwestern Bay of Islands, western Newfoundland, 201

Zahn, R. See Park, M-H., 153

Zentilli, M. See Boric, R., 106; O'Beirne-Ryan, A.M., 120 